\title{
Analysis of Students Failure in Mathematical Problem Solving Based on Newman Procedure at Middle Secondary School 3 Aceh Tamiang District
}

\author{
Siti Rukmana Yus ${ }^{1, *}$, Syafari ${ }^{2}$, Ani Minarni ${ }^{3}$ \\ ${ }^{1}$ Siti Rukmana Yus, Universitas Negeri Medan, Medan, Indonesia \\ ${ }^{2}$ Syafari, Universitas Negeri Medan, Medan, Indonesia \\ ${ }^{3}$ Ani Minarni, Universitas Negeri Medan, Medan, Indonesia \\ *Corresponding author: sitirukmanayus02@gmail.com
}

Received September 15, 2019; Revised November 02, 2019; Accepted November 28, 2019

\begin{abstract}
This research aims to: 1) analyze the types of errors made in solving mathematical problems (MP) based on Newman's procedures by students taught through problem-based learning (PBL); 2) to find the cause of errors in completing the MP based on the Newman procedure after PBL implementation. The subjects in this study were students of class VII Middle Secondary School (MSS) MTsN 3 Aceh Tamiang. Subjects for the purpose of in-depth interviews consisted of six students from different mathematical ability: two students with high ability, two students with moderate ability, and two students with low ability. The object in this study is the completion error in the MPS of students who learning mathematics through PBL on the subject of 'algebraic form'. Based on the results of data analysis, the percentage of students' errors in completing MP was: (1) reading error: $10 \%$; comprehension error: 23.33\%; transformation error: 36.67\%; process skill error: 43.33\%; encoding error: 73.33\%; (2) Specific types of failure made by students in solving math problems happened in: (1) changing questions into their own language, (2) representing problems in the form of mathematical equations, (3) doing calculations, (4) manipulating algebra problems, and (5) interpreting the solution of the problem.
\end{abstract}

Keywords: types of in solving math problem based on the Newman procedure, mathematical problem solving, problem-based learning

Cite This Article: Siti Rukmana Yus, Syafari, and Ani Minarni, "Analysis of Students Failure in Mathematical Problem Solving Based on Newman Procedure at Middle Secondary School 3 Aceh Tamiang District." American Journal of Educational Research, vol. 7, no. 11 (2019): 888-892. doi: 10.12691/education-7-11-20.

\section{Introduction}

In everyday life, there are often various kinds of problems, many of them are inseparable from mathematical problems. Therefore, mathematics needs to be taught to students because mathematics plays several roles as follows: (a) used in all aspects of life, (b) all fields of study require mathematical skills, (c) as a means of strong, concise, and clear communication, (d) can used to present information in a variety of ways, (e) increase the ability to think logically, critically, consistently, (f) provide satisfaction in the efforts to solve challenging problems Meanwhile, Ruseffendi as an education expert stated that generally Indonesian students consider mathematics a subject matter that is difficult to understand and less interesting. Many students feel stressed when going to take mathematics lessons [1].

It is suspected that the problem arises because learning carried out in classroom does not attract students to learn. That is because the learning that is carried out is direct instruction where the teacher gives the whole material without inviting students to be actively involved in constructing their own knowledge. For example, the Pythagorean rule is immediately notified by the teacher to students without inviting students to reinvent it through real problems. Moreover, direct instruction cannot make students have the ability to solve problems [2].

Problem solving is an ability or skill that is very important to obtain, because from birth humans have faced a challenging problem that forced them to find a solution. PBL can be considered as learning model to develop problem solving skills [3]. Because of that, Fogarty views problem solving as having an important role in mathematics [4], likewise mathematics in schools has a significant role in solving mathematical problems and other fields of study such as physics, chemistry, and economics. Problem solving in learning mathematics in schools is usually realized through solving story problems. However, not all story problems will automatically become a problem, as written in the National Council of Teachers of Mathematics (NCTM), "some story problems are not problematic enough for students and hence should only be considered as exercise for students to perform "A question will become a problem only if it shows a 
challenge that cannot be solved by routine procedures that students already know [3].

One learning model that can be used by teachers in teaching and making students active in improving mathematical problem-solving abilities is to use the Problem-Based Learning (PBL) model. This is consistent with the statement of Arends as a pioneer of PBL [4]. Minarni et al. research results found that learning mathematics with PBL is effective in improving mathematical problem-solving abilities [5]. The results of other studies conducted by Ruchaedi showed that the students who received PBL get better improvement in their ability of heuristic strategies as one important aspect in mathematical problem-solving, better than students who received conventional learning (direct instruction) [6].

Mathematical problem solving is a mental process carried out to solve mathematical problems. The ability to solve problems depends on the ability of understanding and representation. According to Newman, when students try to answer a problem in the form of a story problem or a description problem, then the student has passed a series of obstacles in the form of stages in problem solving, they are: (a) Reading a problem, (b) Understanding a problem, (c) Transformation of problems, d) Process skills, (e) Writing of answers (Encoding) [7].

Research conducted by Rohmah \& Sutiarso show that the percentage of students making these five types of errors is quite high, the highest is in the encoding error of $34.78 \%$ [7]. Based on these findings, researchers conducted a study to investigate the types of errors students make in solving mathematical problems based on Newman's procedures after students are taught through PBL as well as investigate the percentage of each type of error. With this research it is expected that teachers can minimize student errors in solving mathematical problems.

\section{Theoretical Framework}

\subsection{Mathematics}

Mathematics has an important role in every human activity, besides that mathematics is also able to develop one's way of thinking. There are five reasons for the need to learn mathematics because they are: (1) a clear and logical means of thinking, (2) a means for solving problems of daily life, (3) a means of recognizing patterns of relationships and generalizing experiences, (4) a means for developing creativity and (5) a means to increase awareness of cultural development.

\subsection{Problem-based Learning}

One learning model that can be used by teachers in teaching and making students active in improving students' mathematical problem-solving abilities is Problem-Based Learning (PBL) \{Arends]. This is in accordance with the statement that Minarni's research findings show that PBL can improve the mathematical problem-solving abilities of junior high school students [8].

The stages that must be done by the teacher in implementing PBL include the following phase [9]:
1. Oriented students to the problems

2. Grouping the students into small group discussion

3. Motivated the students to solve the problems

4. Aid the students to present the solution in front of the class

5. Evaluate the process and the strategies use in solving the problem

PBL has succeeded in improving mathematical understanding [10]. PBL also succeeded in improving mathematical understanding and mathematical representation ability of middle secondary school students [11], and improving mathematical reasoning [12].

\subsection{Mathematical Problem Solving}

Problem solving is an ability or skill needs to achieve by the students, because from human beginning of life has faced a challenging problem that forced him to get a solution [Minarni, [9]. According to Anderson, problem solving is a process of applying knowledge in an unfamiliar situation [13]. Problem solving is an attempt to find a way out of a problem in order to achieve a solution that cannot be achieved immediately [1]. Problem solving in learning mathematics at school is usually realized through story problems. Story problems are one form of problems in mathematics learning that presents problems related to everyday life in the form of stories. However, not all story problems will automatically become a problem, as written in the National Council of Teachers of Mathematics (NCTM) (2010) that "some story problems are not problematic enough for students and hence should only be considered as exercise for students to perform. "A question will become a problem only if it shows a challenge that cannot be solved by routine procedures that students already know [14].

To be able to improve students' mathematical problemsolving abilities, the questions raised to students when learning through PBL must fulfill high order thinking problems, which are complex, challenging, cannot be solved in just one step, related to real life and may have multiple solutions [15].

\subsection{Newman Procedure}

Newman argues that when students try to answer a story problem or a description problem, then the student has passed a series of obstacles stages, including: a) Reading a problem: when someone reads a Text problems, then the reader will be represented in accordance with his understanding of what he reads [7]. Furthermore, students' reading a problem influences how students solve mathematical problems; b) Understanding the problem: at this stage students are said to be able to understand mathematical problems, if students understand the purpose of the problem so that students are able to state the problem in their own sentences. At this stage, students should be able to show ideas of mathematical problems such as: "What, Why, Where, When, Who, and How", This knowledge represented in the elements known, asked and prerequisites of the problem. Furthermore, it can be concluded from Rahmah \& Sutiarso that to check the ability to understand the problem, students are asked to mention what is known and asked in mathematical 
problems; c) Transformation problems, in this stage students try to find the relationship between what is known and what the problem asked. Furthermore, to check the ability to transform a problem, the students are asked to transform problem to mathematical model, to their own words, or to other representation forms; d) Process skills (Process Skill), is the stage where students are asked to implement the strategy to solve the problem to produce a desired solution; e) Writing answers (Encoding), in this stage students are said to have reached the stage of encoding if the students can write the solution as exactly as possible in accordance with requested problem [7].

Furthermore, to check the ability of students to write answers, students are asked to check back on the answers and students are asked to interpret the final answers obtained. The research shows that based on the Newman procedure, students make a type of error in reading ability as much as $4.35 \%$, comprehension the problem is about $17.39 \%$, transformation error is $34.78 \%$, errors in writing the final answer (encoding error) 23.91\%, then the process skill error is $19.37 \%$ [7].

\section{Research Methods}

This research is located at middle secondary school (MSS) MTsN 3 Aceh Tamiang which is carried out in a structured and systematic manner. The research is conducted at the odd semester of the academic year 2019/2020. In this study the population wa grade VII students. The sample size of this study was 30 students at grade VII MSS MTs 3 Aceh Tamiang District. This type of research is qualitative research.

The instrument used to collect MPS data is a description test consisting of 3 questions. Then, the test solution will be analyzed using the Newman procedure which includes: (1) reading stage, (2) comprehension stage, (3) transformational stage, (4) process skill stage, (5) encoding stage. Mathematical material that will be used to design problems is two-variable linear equations.

Qualitative analysis [16] is used to analyze data errors made by students in solving mathematical problems based on Newman's procedures. So, an inventory of the types of errors students make in answering MPS test questions and the percentage for each type of error will be inventoried. The test is carried out after students learn mathematics through PBL.

After obtaining data regarding the percentage and type of student errors in solving mathematical problems based on Newman's procedures, the data will be analyze and elaborated to obtain conclusions.

\section{Research Results}

Data of student MPS ability is presented in Table 1 below.

Table 1. Level of Students Mathematical Problem-Solving Ability

\begin{tabular}{|c|c|c|c|}
\hline No & Total students & Percentage & Category \\
\hline 1 & 8 & 26.67 & High \\
\hline 2 & 13 & 43.33 & Medium \\
\hline 3 & 9 & 30.00 & Low \\
\hline
\end{tabular}

The types of errors students make in completing MPS questions based on Newman's procedures are presented in Table 2 below.

Table 2. Percentage of students in each type of error

\begin{tabular}{|c|c|c|c|c|}
\hline No & $\begin{array}{c}\text { Mistakes made } \\
\text { by students }\end{array}$ & Indicator & $\begin{array}{c}\text { Total } \\
\text { students }\end{array}$ & Percentage \\
\hline 1 & Reading & $\begin{array}{l}\text { Mistakes in } \\
\text { reading important } \\
\text { words in the } \\
\text { problem and } \\
\text { wrong in reading } \\
\text { the information } \\
\text { in the problem }\end{array}$ & 1 & 3.30 \\
\hline 2 & Comprehension & $\begin{array}{l}\text { Students can } \\
\text { actually } \\
\text { understand the } \\
\text { problem, but } \\
\text { have not captured } \\
\text { the information } \\
\text { contained in the } \\
\text { question }\end{array}$ & 7 & 23.33 \\
\hline 3 & Transformation & $\begin{array}{l}\text { Students fail to } \\
\text { understand the } \\
\text { questions to be } \\
\text { converted into } \\
\text { correct } \\
\text { mathematical } \\
\text { sentences }\end{array}$ & 11 & 36.67 \\
\hline 4 & Process Skill & $\begin{array}{l}\text { Students in using } \\
\text { rules or rules are } \\
\text { correct, but } \\
\text { wrong in doing } \\
\text { calculations or } \\
\text { computing } \\
\end{array}$ & 13 & 43.33 \\
\hline 5 & Encoding & $\begin{array}{l}\text { Error writing the } \\
\text { final result or } \\
\text { error in } \\
\text { concluding }\end{array}$ & 22 & 73.33 \\
\hline
\end{tabular}

From Table 2 above, it was found that students who experienced errors based on the Newman procedure, namely the lowest percentage was in reading error, which was $10 \%$, the highest percentage was in the encoding skill, which was $73.33 \%$.

Overall, this research found the following:

1. Mistakes made by students in solving problem based on Newman's procedures:

a. There are no more students who experience errors in reading problem.

b. Only $6.7 \%$ of students (2 out of 30 research subjects) were still experiencing errors understanding the problem.

c. Only $13.4 \%$ of students still experience errors in process skills.

d. $20.3 \%$ of students still have errors writing the final answer.

2. Causes of student errors in solving problem solving problems based on Newman's procedure:

a. Comprehension errors:

The student face difficulty in finding what is known and asked in the problem, experience difficulty in identifying what is known correctly so that it results in misinterpretation, could not reading the problem carefully so that there is information about the problem missed, could not understand the overall meaning of the problem properly so it is inconsistent in identifying what is known to be asked in the problem, unable to explain the 
information contained in the problem correctly, forgetting to write what is known and what is asked in the problem.

b. Transformation error:

Unable to plan the strategy to solve the problem, have not accustomed to to transform problem into mathematical form, not having the ability to change what is cheated into mathematical form, not understanding the definition of algebraic form, haste in solving problems because time is running out. As an addition, the students are lack of selfconfidence to solve the problems, they do not like mathematics, lack of practice in solving story problems in relation to algebraic material, and have low other cognitive abilities.

c. Process skills errors:

Errors resulting also happened as a consequences of previous mistakes, the student was not realized that they have made mistakes on the count operations performed, unable to perform the count operations correctly, not understanding the calculations in a sequential or structured way, and wrong in choosing mathematical operations.

d. Encoding errors:

Not checking the answers before they are collected, and could not interpreted the solution obtained.

Some figures presented here shows example of student failure in solving mathematical problem based on Newman procedure. Figure 1 is an example of solving a mathematical problem from a student who made a transformation error. Students write " $4+\mathrm{x}$ and $3+\mathrm{y}$ " to represent 4 pieces of T-shirts and 3 pieces of pants ". He should have written " $4 \mathrm{x}$ and $3 \mathrm{y}$ " because of $\mathrm{x}$ variable represent $\mathrm{T}$-shirt, and y variable represent pants.

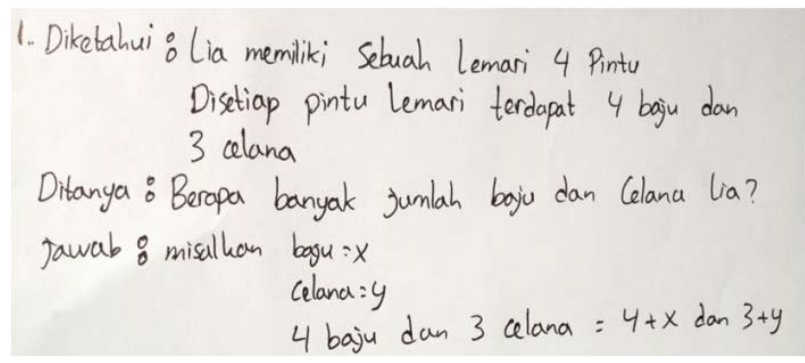

Figure 1. Student answer to Problem number 1

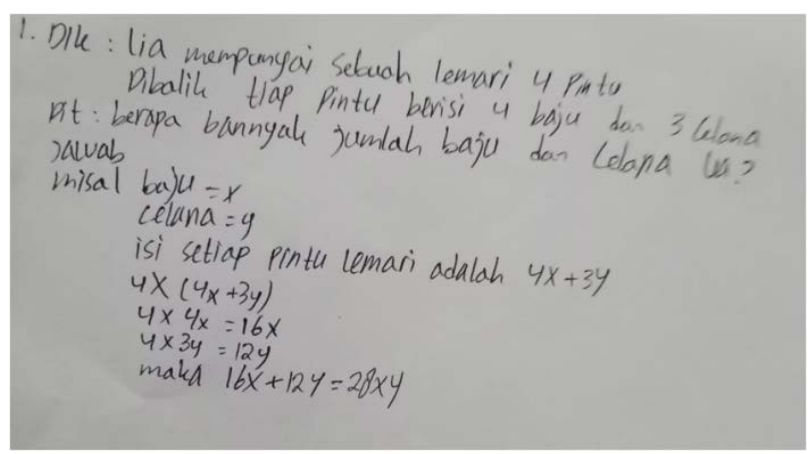

Figure 2. Student answer to Problem number 1 with comprehension error

Figure 2 is an example of mathematical problem solution number 1 . In solving these problems students do not understand how to do algebraic operations correctly.
This student lacks the ability to understand algebra. According to the Newman procedure, these students lack the comprehension stage in the problem solving process [7].

Figure 3 below presents the solutions given by students to the mathematical problem number 1 with the error encoding stage of the Newman procedure.

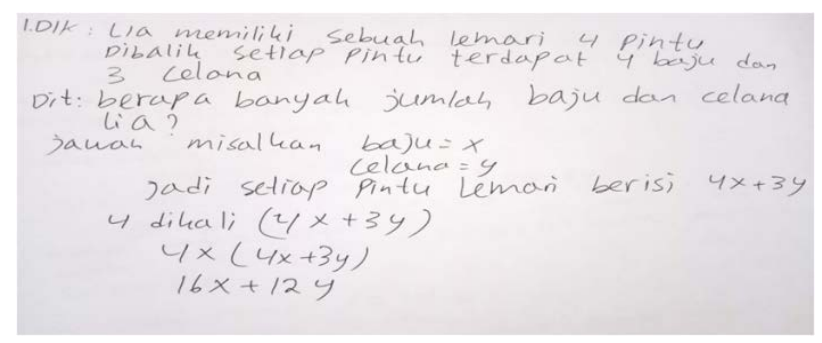

Figure 3. Student answer to Problem number 1 with encoding error

The solution given by students in Figure 3 shows students' mistakes in the encoding stage of the Newman procedure. After students take part in learning mathematics through PBL, the percentage of students making these mistakes is quite small. This is because during the learning process the teacher encourages students to try to make mathematical models for mathematical problems given in the student's worksheet, in accordance with the demands of the PBL theory [5]. After repeatedly doing this, students become fond of making mathematical models for each given problem.

Figure 4 below presents the solutions given by students to the mathematical problem number 1 with the complete stage of the Newman procedure.

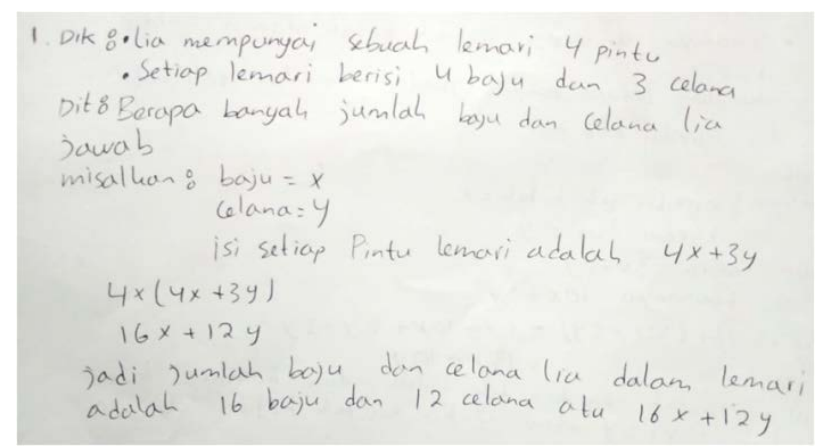

Figure 4. Student answer to Problem number 1 with there is not error

The solution given by students in Figure 4 is an example of mathematical problem solution number 1 . In solving these problems students do understand how to do algebraic operations correctly. This student lacks the failure to understand algebra. According to the Newman procedure, these students complete the comprehension stage in the problem solving process [7].

\section{Conclusion}

After students learn mathematics through PBL, the mistakes made by students in solving mathematical problems based on Newman's procedures have greatly decreased in every aspect including comprehension error, transformation error, process skills error, and encoding error. The low percentage error occur at the stage of 
reading the problem that is $0 \%$. The high percentage error occur at encoding stage that is $20 \%$. Thus, it is still needed to continue learning mathematics through PBL so that the students could make minimum error in every stage of problem solving based on Newman Procedure.

\section{References}

[1] Ruseffendi, E.T. 1992. Pendidikan Matematika 3. Jakarta: Depdikbud

[2] Ronis, D., L. (2008). Problem-based Learning for Math \& Science; Integrating Inquiry and the Internet. California: Corwin Press.

[3] Ronis, D., L. (2008). Problem-based Learning for Math \& Science; Integrating Inquiry and the Internet. California: Corwin Press.

[4] Fogarty, R. (1997). PBL in Other Curriculum Models for Multiple Intelligence Classroom. Melbourne, Vic: Hawker Bronlow Education.

[5] Branca, N.A., (1980). Problem Solving as a Goal, Process, and Basic Skill. Dalam Krulik, S. (ed). Problem Solving ini School Mathematics. 1980 Yearbook. Reston, VA: NCTM.

[6] Ruchaedi, D., Suryadi, D., Herman, T. 2017. Pengaruh Problem Based Learning (PBL) Terhadap Kemampuan Heuristik Pemecahan Masalah dan Sikap Matematis Siswa Sekolah Dasar, Jurnal Eduhumaniora Pendidikan Dasar . Vol 7, No 1.

[7] Rohmah, M. \& Sutiarso, S. (2018). Analysis Problem Solving in Mathematics Using Newman Theory. Eurasia Journal Math., Sci Tech.: 14(2), 671-681.
[8] Minarni, A. \& Napitupulu, E. E. (2018). Eight Grade Mathematical Problem Solving Ability: Public School Case. Conference Proceeding of the $3^{\text {rd }}$ Annual International Seminar on Transformative Education and Educational Leadership (AISTEEL 2018).

[9] Arends, R.I. (20r04). Learning to Teach, $6^{\text {th }}$ Edition. New York: The McGraw-Hill Company, Inc.

[10] Posamentier, A., S., and Krulik, S. (2009). Problem Solving in Mathematics: Grade 3-6: Powerful Strategies to Deepen Understanding. California: Corwin Publisher.

[11] Minarni, A. \& Napitupulu, E. E. (2017). Developing Instruction Materials Based on Joyful PBL to Improve Students Mathematical Representation Ability. International Education Studies; Vol. 10, No. 9, pp. 23-38.

[12] Napitupulu. E.E., Suryadi, D., \& Kusumah, Y.S. (2016). Cultivating Upper Secondary Students’ Mathematical Reasoning Ability and Attitudes towards Mathematics through ProblemBased Learning. Indo-MS Journal on Mathematics Education, Vol. 7. No. 2, pp 61-71.

[13] Anderson, L.W., et al., (2001). A Taxonomy for Learning, Teaching, and Assessing. New York: Addison Wesley Longman, Inc.

[14] NCTM. (2000). Principle and Standards for School Mathematics. Reston: VA.

[15] Resnick, L. B. (1987). Education and Learning to Think. Washington DC: National Academic Press.

[16] Berg, Laurence, B., \& Lune, H. (2008). Qualitative Research Methods for the Social Sciences. Boston: ISBN 9780205809387.

(C) The Author(s) 2019. This article is an open access article distributed under the terms and conditions of the Creative Commons Attribution (CC BY) license (http://creativecommons.org/licenses/by/4.0/). 